\title{
A case of intraspecific killing in passerines: the House Sparrow (Passer domesticus)
}

\author{
Guillaume Halliez ${ }^{1,2^{*}} \&$ Clémence Marie Lucie Becel ${ }^{2}$
}

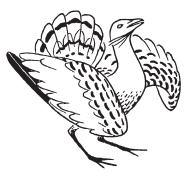

Guillaume Halliez \& Clémence Marie Lucie Becel 2014. A case of intraspecific killing in passerines: the House Sparrow (Passer domesticus). - Ornis Hungarica 22(2): 126-129.

nes constitute a very small percentage of published reports, and many of the cases are based on circumstantial evidence. In March 2013, we witnessed a group of House Sparrows (Passer domesticus) kill a conspecific male adult in the village of Gonsans (France, Doubs department). During the reproductive season three explanations of others studies (lack of food, weak condition and territorial behaviour during) could be relevant in our case. In conclusion, it appears that our observation is a very rare one and the second one for the House Sparrow.

Keywords: House Sparrow, aggressive event, intraspecific killing, intraspecific competition, passerines

Összefoglalás Míg a fajtársak közötti összetüzés jól ismert viselkedés a madaraknál, a verébalkatúak rendjén belül, a fajtársak megölése az irodalomban ritkán említett jelenség. Ilyen esetben is inkább közvetett bizonyítékok állnak rendelkezésre. 2013 márciusában a franciaországi Gonsans nevủ faluban egy kisebb házi verébcsapat (Passer domesticus) egy fajtársa megölésének voltunk szemtanúi. Tekintve, hogy ez a téli időszak vége és a szaporodási szezon kezdete, így az élelemhiány, az áldozat rossz fizikai kondíciója és a territoriális viselkedés bármelyike magyarázhatja a történteket. Mindössze egy ilyen jellegủ eseményt publikáltak ezelött a házi veréb esetén.

Kulcszavak: házi veréb, agresszió, fajtársak közötti gyilkosság, versengés, énekesmadarak

${ }^{1}$ Chrono-Environnement Laboratory, University of Franche-Comté/CNRS - 16 route de Gray, Besançon, France, e-mail:doctorant@fdc25.com

${ }^{2}$ Universitary Group of Naturalists of Franche-Comté - 16 route de Gray, Besançon, France

*corresponding author

\section{Introduction}

Despite considerable interest in its occurrence or potential occurrence (e.g. Lorenz 1963), both direct and circumstantial evidence of intraspecific killing in adult passerines is rare (Davis 1940, Cottrille 1950, Joslin 1964, Clevenger \& Roest 1974, Fisher 1975, Grubbs 1977, Loflin 1982, Cawston 1983, Lombardo 1986, Andersen 2004). Our aim was to contribute to this meagre body of literature with the second observed case of intraspecific killing in adult House Sparrow (Passer domesticus).

\section{Description of the observation and the environmental context}

Our study site is the village of Gonsans in France $\left(47^{\circ} 13^{\prime} 58^{\prime \prime} \mathrm{N}, 6^{\circ} 18^{\prime} 04^{\prime \prime} \mathrm{E}\right)$. This village is about 545 inhabitants with a surface of $17.29 \mathrm{~km}^{2}$ (density of 32 inhabitants per $\mathrm{km}^{2}$ ) represents a normal size for a village in Franche-Comté area and in France. This village is situated at the beginning of the medium mountain stage (from 500 to 600 meters of elevation). The buildings are composed of old renovated farms in the downtown of the village and new houses in the periphery. The 
buildings are rarely taller than two floors. Urbanized areas are known to be friendly for the House Sparrow (Bichet et al. 2013). In Franche-Comté, the study of the House Sparrow allows us to consider that the density of the species is about 70 individuals per $\mathrm{km}^{2}$ (Legay \& Weidmann 2005). In the very local urban area where we were (about 10 houses) we observed a maximum of seven different individuals for a number of couple of three. The landscape around the village is composed by grassland and mixed forested areas (Giraudoux et al. 1997).

On $7^{\text {th }}$ March 2013 at 9 a.m., we observed an adult male House Sparrow attacked by four others of the species as three adult males and one adult female. We missed the beginning of the combat. We were located 25 meters from the event, which was occurred less than 50 meters from the closest source of food (bakery and bird table) or nesting place. The male was on the ground in the middle of the street and the four other individuals pecked the head of the victim alternatively for almost twenty minutes killing him slowly but certainly. The victim was still alive during the aggressive event (moving slowly) and we examined the corpse after the observation to be sure that the individual was dead and we did not find any clue of an injury by another source (car, predation etc.).

In March, the sparrows were still feeding on pieces of bread from the bakery and sunflower seeds distributed by people situated less than 50 meters from the event. This period (the end of winter/beginning of spring) corresponds to the start of the reproductive season meaning territorial behaviour from potential reproducers and also the existence of differences in body condition between individuals because of the lack of food during winter.

We observed mated pairs starting to build nests in holes below the roofs close to the event (less than 50 meters away). After the aggressive event the four aggressors returned to the building of nests. The victim seemed to be unable to fly or fight off the aggressors.

Considering the fact that we observed the victim alive during the event, was it because of a hurt present before or because of the aggressive event, sickness, our observation cannot bring efficient information to answer.

\section{Discussion}

Grubbs (1977) described for the first time for the same species a similar case of intraspecific killing without be able to explain it. One sparrow held the other one by the neck and after a few seconds the struggling victim became still. The attacking sparrow, still on top of the nearly lifeless one, began to hammering on the head of the victim. Several sparrows flew near, then all flew away leaving the motionless body on the ground. Minutes later a sparrow returned, jumped on the dead sparrow and again struck it on the head several times, then flew away. This evidence indicates that House Sparrows are capable of causing mortal wounds on one another.

Kuerzi (1941) presented evidence of intraspecific killing in Tree Swallows (Tachycineta bicolor) and reported two fights between a male and a female in brown plumage. During one fight the brown female had the male pinned on the ground, and she pecked at the back of his head until he escaped when Kuerzi approached for a better view. This observation of Kuerzi (1941) is similar to ours with the same 'pecking on the head' behaviour.

In birds, we found additional descriptions of intraspecific killing in avian species including Egretta sacra, Arenaria interpres, Passer domesticus, Motacilla alba (Joslin 
1964, Grubbs 1977, Crossland 1995, Beckmann 2008). Each time, the attacker(s) killed by pecking on the head of the victim. The potential explanations by those authors are bad body condition or territorial mechanism during reproduction season while the lack of food was never mentioned. During the body inspection of Arenaria interpres, Crossland (1995) found the female victim in very poor condition: it weighed only 64.2 grams against a normal average of 100.3 to 170.2 grams (Huston \& Barter 1990) while during the body inspection of Egretta sacra, Beckmann (2008), it was found that the victim was in poor body condition, and likely starving. In the case of Motacilla alba, Joslin (1964) added that there was a new but incomplete nest inside another green house about 50 feet away, where these birds had produced up to three clutches annually for several years. Another common observation of those authors is that there was always more than one attacker (between 2 and 25) and the attackers could be either male or female.

In Passerines (shrikes (Laniidae) excluded), the Great Tit (Parus major) is known to be aggressive (until killing by pecking on the head) towards both Passerines (Common Repoll Carduelis flammea, Yellowhammer Emberiza citrinella, Pied Flycatcher Ficedula hypoleuca) and bats (Caris 1958, Barnes 1975, Gosler 1993, Selva et al. 2005, Estók et al. 2010). This aggressive behaviour of the Great Tit is explained both by lack of food in winter (Drent et al. 2003) and territorial mechanism during the reproductive season (Krebs 1982, Drent et al. 2003). As we previously explained, we did not observe the beginning of the event and did not see visible injuries on the body of the victim other than the one at the head caused by the aggressive event. Potential contributing factors observed during the event included very localized sources of food (bakery and bird table) and very localized places to nest (roofs). Because of this and considering the period (end of winter and the beginning of the reproductive season), the three explanations of the cited studies (lack of food, bad body condition and territorial mechanism during the reproductive season) could be relevant in our case.

Intraspecific predation is often a function of density. Polis (1981) found 65 reports of increased predation rates due to overcrowding or high densities in birds, fishes and invertebrates (Fox 1975, Polis 1980). There are two possible explanations for this relationship. First, changes in the rate of intraspecific killing occur because predators exhibit density-dependent responses to heterospecific prey as well as for homospecific prey. Second, individuals of many species maintain inter-individual space or territory in which they are intolerant to conspecifics. Crowding caused by the searching for a sexual partner increases the frequency with which conspecifics violate a critical minimum individual distance (intraspecific space) and thus promotes the observed increase in the rate of intraspecific killing. Finally, ethologists have insisted that intraspecific killing and predation in passerines are rare events in the environment. They have stressed that passerine fighting is commonly restrained by ritual, bluff and nonfatal violence (Polis 1981).

In conclusion, it appears that our observation is a very rare one and the second one for the House Sparrow. The literature provides some potential explanations in different cases of intraspecific killing, such as bad body condition, territoriality during reproduction period or lack of food. Considering the period (the end of the winter and the beginning 
of the reproductive season), all three explanations could be relevant in our case. The lack of knowledge about intraspecific killing in passerines must lead to more specific studies than local observations as ours.

\section{References}

Andersen, E. M. 2004. Intraspecific predation among Northwestern Crows. - The Wilson Bulletin 116(2): 180-181. DOI: 10.1676/03-113

Barnes, J. A. G. 1975. The Titmice of the British Isles. - David \& Charles, Newton Abbot, pp. 212

Beckmann, C. 2008. An intraspecific killing in adult Pacific Reef Egrets (Egretta sacra). - The Wilson Journal of Ornithology 120(2): 422-424. DOI: 10.1676/07-097.1

Bichet, C., Scheifler, R., Coeurdassier, M., Juillard, R., Sorci, G. \& Loiseau, C. 2013. Urbanization, trace metal pollution and malaria prevalence in the House Sparrow. - PLoS ONE 8(1):e53866. DOI: 10.1371/journal.pone.0053866.

Caris, J. L. 1958. Great Tit killing and carrying Goldcrest. - British Birds 51: 355.

Cawston, J. M. 1983. One Moorhen killing and eating another. - British Birds 76: 451.

Clevenger, G. A. \& Roest, A. I. 1974. Cannibalism in Red-tailed Hawk. - The Auk 91: 639.

Cottrille, B. D. 1950. Death of a Homed Lark in territorial combat. - The Wilson Bulletin 62: 134-135.

Crossland, A. C. 1995. A probable case of intraspecific killing in Turnstones (Arenaria interpres). - Notornis 42: 281-282.

Davis, D. E. 1940. Social nesting habits of the Smoothbilled Ani. - The Auk 57: 472-484.

Drent, P. J., van Oers, K. \& Noordwijk, A. J. V. 2003. Realized heritability of personalities in the Great Tit (Parus major). - Proceedings of the Royal Society, Series B: 270: 45-51. DOI: 10.1098/ rspb.2002.2168

Estók, P., Zsebők, S. \& Siemers, B. M. 2010. Great Tits search for, capture, kill and eat hibernating bats. - Biology Letters 6: 59-62. DOI: 10.1098/ rsbl.2009.0611

Fisher, B. M. 1975. Possible intra-specific killing by a Great Gray Owl. - Canadian Field Naturalist 89: 71-72.

Fox, L. R. 1975. Cannibalism in natural populations. - Annual Review of Ecology and Systematics 6: 87-106.

Giraudoux, P., Delattre, P., Habert, M., Quéré, J. P., Deblay, S., Defaut, R., Duhamel, R., Moissenet, M. F., Salvi, D. \& Truchetet, D. 1997. Population

\section{Acknowledgement}

We want to thanks Ms Petra Villette for checking the English of this article.

dynamics of fossorial Water Vole (Arvicola terrestris scherman): a land use and landscape perspective. - Agriculture, Ecosystems and Environment 66: 47-60.

Gosler, A. G. 1993. The Great Tit. - Hamlyn Ltd., London, pp. 155

Grubbs, V. L. 1977. An intraspecific mortal attack. The Wilson Bulletin 89: 477.

Huston, P. \& Barter, M. 1990. Morphometrics of Ruddy Turnstone (Arenaria interpres) in Australia. The Stilt 17: 17-23.

Joslin, D. 1964. Male Pied Wagtail killing another and persistently attacking the corpse. - British Birds 57: 329-330.

Krebs, J. R. 1982. Territorial defence in the Great Tit (Parus major): do residents always win? - Behavioral Ecology and Sociobiology 11: 185-194.

Kuerzi, R. G. 1941. Life history studies of the Tree Swallow. - Proceedings of the Linnean Society, N.Y. 52-53: 1-52.

Legay, P. \& Weidmann, J. C. 2005. Suivi temporel des oiseaux communs par points d'écoute (STOC EPS) [Temporal monitoring of common birds by listening points (STOC EPS)]. - Bilan de la saison 2005 en Franche-Comté, p. 13. (in French)

Loflin, R. K. 1982. Ani male apparently killed by other Anis while attempting to parasitize nest. - The Auk 99: 787-788.

Lombardo, M. P. 1986. A possible case of adult intraspecific killing in the Tree Swallow. - The Condor 88: 112.

Lorenz, K. Z. 1963. On aggression. - Harcourt, Brace, and World, New York, pp. 306

Polis, G. A. 1980. The effect of cannibalism on the demography and activity of a natural population of desert scorpions. - Behavioral Ecology and Sociobiology 7: 25-35.

Polis, G. A. 1981. The evolution and dynamics of intraspecific predation. -Annual Review of Ecology and Systematics 12: 225-251.

Selva, N., Jędrzejewska, B., Jędrzejewski, W. \& Wajrak, A. 2005. Factors affecting carcass use by a guild of scavengers in European temperate woodland. - Canadian Journal of Zoology 83: 15901601. DOI: $10.1139 /$ z05-158 